\title{
MET Amplification Status
}

National Cancer Institute

\section{Source}

National Cancer Institute. MET Amplification Status. NCI Thesaurus. Code C157251.

A procedure used to detect amplifications involving all or part of the MET gene. 